\title{
CHARACTERIZATION AND ANTI-NEOPLASTIC POTENTIAL OF PHYTOFABRICATED SILVER NANOPARTICLES ON HUMAN BREAST CANCER CELL LINE (MCF-7)
}

\author{
CHINNAIAH KUPPUSWAMY AMUDHA ${ }^{1}$, FARAH DEEBA ${ }^{1}$, PETHANNAN RAJARAJAN ${ }^{2}$
}

${ }^{1}$ School of Science Studies, CMR University, HRBR Layout, Bangalore 560043, India, ${ }^{2}$ Department of Microbiology, Center for Research and PG Studies, Indian Academy Degree College-Autonomous, Hennur Cross, Kalyan Nagar, Bangalore 560043, India

Email: rajarajanbioscience@gmail.com

Received: 11 Jun 2019, Revised and Accepted: 02 Sep 2019

\section{ABSTRACT}

Objective: The surging cancer incidence has necessitated the synthesis, characterization and production of green synthesized silver nanoparticles and its effective use. The present study was carried out to assess the antineoplastic potential of the green synthesized silver nanoparticles against breast cancer cell lines.

Methods: The rapid biological synthesis of silver nanoparticles was done using Withania somnifera, Aegle marmelos and Taraxacum officinale. The synthesized nanoparticles were characterized using Scanning Electron Microscope (SEM), Energy Dispersive X-Ray Spectroscopy (EDX) and Fourier Transform Infra-Red (FTIR) analysis. Further, the antineoplastic potential of the green synthesized nanoparticles were assessed by MTT assay at an ascending concentration of $25,50,100,250,500 \mu \mathrm{g} / \mathrm{ml}$ against MCF-7 (Breast) cancer cell lines.

Results: The synthesized nanoparticles were characterized using SEM, EDX and FTIR analysis which confirmed the formation of silver nanoparticles and were of irregular shape with a size of $26 \mathrm{~nm}, 18 \mathrm{~nm}, 94 \mathrm{~nm}$, and its IC50 value was $251.2563 \pm 0.59 \mu \mathrm{g} / \mathrm{ml}, 215.5172 \pm 0.41 \mu \mathrm{g} / \mathrm{ml}$ and $205.7613 \pm 0.37 \mu \mathrm{g} / \mathrm{ml}$ for Aegle marmelos, Taraxacum officinale and Withania somnifera respectively against MCF-7 cells.

Conclusion: The investigation unveils the fact that phytofabricated AgNPs could be exploited as an effective antineoplastic agent for further medical and pharmaceutical applications.

Keywords: Green synthesis, Silver nanoparticles, Breast cancer

(C) 2019 The Authors. Published by Innovare Academic Sciences Pvt Ltd. This is an open-access article under the CC BY license (http://creativecommons.org/licenses/by/4.0/) DOI: http://dx.doi.org/10.22159/ijap.2019v11i6.34528

\section{INTRODUCTION}

Nanotechnology has become a rising and promising field in Science and Technology being used in the process of manufacturing new materials at the nanoscale level such as nano products and nanoparticles (NPs) that have the novel and size-related physiochemical properties and differ greatly from their macro-sized counterparts. These nanostructures vary between 1 to 100 nanometers (nm) [1-3]. There is an increasing demand for the synthesis of nano-particles which is normally required to be synthesized by "Green Synthesis Mechanism" in order to reduce the hazardous wastes generated during the process which has a Global Impact. In this effort Green Chemistry and chemical processes are used for the modern development of nanoparticles [3]. Nano-particles have enormous use in areas such as optics, biomedical sciences, chemical industry, drug-gene delivery, energy science, catalysis [4]. With the large outbreak of infectious diseases by different pathogens and development of antibiotic-resistant strains, the need for new antimicrobial agents has emerged. In such a scenario, nanomaterials are found to be effective and novel antimicrobial agents due to their high surface area to volume ratio and their unique chemical and physical properties [5-7]. Different metals like copper, zinc, titanium [8], magnesium, gold $[5,9]$ and silver are used for the synthesis of stable dispersions of nanoparticles among which silver nanoparticles have found to be the most efficient due to their enhanced antimicrobial efficacy against bacteria, viruses and other eukaryotic micro-organisms $[5,10]$.

Cancer has become one of the major reasons of morbidity and mortality in the world. The most common types of cancer include breast, prostate, colorectal, lung carcinoma and melanoma [11]. Normally, cancer is caused due to alterations in the genetic control of cell division leading to uncontrolled cell division. In general, genes encoding cyclin-dependent kinase (CDK), cyclins, CDK-activating enzymes, CK1, CDK substrates and check proteins undergo mutations leading to cancer [12]

Breast cancer is the most common form of cancer in women worldwide with incidence occurring more in women of age 50 and above. There has been an increase in breast cancer due to changes in reproductive patterns such as delayed childbearing and having fewer children [13]. Breast cancer is a heterogeneous disease composed of a large number of biological subtypes and depends on genetic influences, differences in lifestyle or nutritional or environmental exposure [14]. Over the years, studies have also proven that the increased rates of breast cancer in patients having a family history concluding that it can be genetically inherited [15]. Hence, the present study was focused on the antineoplastic potential of the green synthesized silver nanoparticles against the predominant cancer type in women viz. breasts through their respective cancer cell lines.

\section{MATERIALS AND METHODS}

\section{Collection of plant materials}

Healthy leaves of plants were collected from Green India Nursery, Varthur, Bangalore-560087 and authenticated at Gandhi Krishi Vignana Kendra (GKVK), University of Agricultural Sciences, Bangalore as Withania somnifera, Aegle marmelos and Taraxacum officinale with voucher specimen number UASB-459A, UASB-459B and UASB-459C. Fresh Leaves were washed several times with water to remove the dust particles, shade dried to remove the residual moisture and ground to form powder [16].

\section{Preparation of leaf extract}

The leaf extract solution was prepared using $50 \mathrm{~g}$ of leaves that had been rinsed with deionized water and finely cut into small pieces. The chopped leaves were boiled in $50 \mathrm{ml}$ of deionized water for 20 $\mathrm{min}$ and allowed to cool. Then subjected to centrifugation for $30 \mathrm{~min}$ at $5000 \mathrm{rpm}$ under room temperature. The cooled leaf broth was filtered and stored in a refrigerator at $4{ }^{\circ} \mathrm{C}$. The resulting extract was used as a leaf extract solution [17]

Preparation of silver nanoparticles

Silver nitrate (AgNO3) was used as a precursor for the synthesis of silver nanoparticles. Silver nanoparticles (AgNP) were prepared by 
adding $25 \mathrm{ml}$ of plant extract to $75 \mathrm{ml}$ of $1 \mathrm{mmol}$ silver nitrate (SD Fine Chem Limited, Mumbai) to give a final concentration of 0.1 mmol at room temperature. A distinct colour change was observed after $2 \mathrm{~min}$, the solution turned to dark yellow from normal colourless solution, suggesting the synthesis of silver nanoparticles. The colour became darker and turned into dark brown after $5 \mathrm{~min}$. The reduction of silver ions was confirmed by the UV-Vis spectrum of the solution. The synthesized nanoparticles were separated out from the mixture by centrifugation at $10,000 \mathrm{rpm}$ for $20 \mathrm{~min}$. Centrifugation process was repeated for 3 to 4 times by dispersing pellet in distilled water for removing organic matters of leaf extract. The pellet was collected carefully from the bottom of the centrifuge tube in a watch glass and dried in a hot air oven at $60^{\circ} \mathrm{C}[17,18]$. All the chemicals used in this study were of analytical grade.

\section{Characterization of silver nanoparticles}

\section{SEM analysis}

Scanning electron microscopy (SEM) is a technique that uses electrons instead of light to form an output image. The morphological features of synthesized silver nano-particles from Withania somnifera, Aegle marmelos, Taraxacum officinale leaf extract were studied by Scanning Electron Microscope (JEOL-JSM$6480 \mathrm{LV}$, USA). After $24 \mathrm{H}$ of the addition of AgNO3, the samples were characterized in SEM at an accelerating voltage of $20 \mathrm{KV}$ [17].

\section{Energy-dispersive X-ray spectroscopy (EDX)}

EDX is a technique that provides the elemental curve as output and is generally used in conjunction with the SEM. EDX technique primarily detects the X-rays emitted from the sample during the process of bombardment by an electron beam for characterizing the elemental composition of the sample of interest [19].

\section{Fourier transform infra-red (FTIR) analysis}

This was carried out for the control samples and the test samples. FTIR measurement was studied by using FTIR spectrometer (Perkin-Elmer LS-55-Luminescence spectrometer, USA) for Withania somnifera, Aegle marmelos, Taraxacum officinale leaf extract and silver nano-particles to identify the possible bioactive molecules responsible for the reduction of the Ag+ions and the capping of the bio reduced silver nanoparticles by the leaf extract, in the diffuse reflectance mode at a resolution of $4 \mathrm{~cm}^{-1}$ using potassium bromide pellets (SD Fine Chem Limited, Mumbai) and the solutions were dried at $75^{\circ} \mathrm{C}$ and the dried powders were characterized. The spectrum was recorded in the wavelength interval of 4000 to $400 \mathrm{~cm}^{-1}$ [20].

\section{In vitro cytotoxicity assays}

\section{MTT assay}

The cells (MCF-7) and test compounds like (3-(4,5-dimethylthiazol-2yl)-2,5-diphenyl tetrazolium bromide) (MTT) reagent (Sigma-aldrich, India) were prepared in 96-well plates containing a final volume of $100 \mathrm{\mu l} /$ well and incubated for the desired period of exposure $(1$ to $4 \mathrm{~h}$ at $37{ }^{\circ} \mathrm{C}$ ). $10 \mu \mathrm{l}$ MTT solution was added per well to achieve a final concentration of $0.45 \mathrm{mg} / \mathrm{ml}$. To dissolve formazan crystals, $100 \mu \mathrm{l}$ solubilisation solution was added to each well. Absorbance was recorded at $570 \mathrm{~nm}$. The cell viability was calculated using the equation:

$$
\begin{aligned}
& \text { Cell viability }(\%)=(\text { Absorbance of treated cells } / \text { Absorbance of } \\
& \text { control cells) } \times 100
\end{aligned}
$$

The assays were performed in triplicates. IC50 value was calculated, as the concentration of samples at which $50 \%$ of samples are viable when compared to control cells [21].

\section{Apoptosis/Dual/A0-EB fluorescent staining}

The cells were treated with test compound at IC50 concentration and incubated for $24 \mathrm{~h}$ in $\mathrm{CO} 2$ incubator at $37^{\circ} \mathrm{C}$. The cells were removed by trypsination and collected by centrifugation including the non-adherent cells. The cell pellet was resuspended in medium and dual fluorescent staining solution $(1 \mu \mathrm{l})$ containing $100 \mu \mathrm{g} / \mathrm{ml}$ $\mathrm{AO}$ and $100 \mu \mathrm{g} / \mathrm{ml} \mathrm{EB}$ (AO/EB, Sigma, St. Louis, MO) was added to each suspension and cell suspensions $(25 \mu \mathrm{l})$ were transferred to glass slides. Dual fluorescent staining solution $(1 \mu \mathrm{l})$ containing $100 \mu \mathrm{g}$ each in suspension was added and then covered with a cover slip. The morphology of apoptotic cells was examined and the cells were counted within $20 \mathrm{~min}$ using a fluorescent microscope [22].

\section{DNA fragmentation assay}

The inter-nucleosomal cleavage of DNA was analysed by DNA fragmentation assay. The cells were briefly treated with the appropriate concentration of test solutions for $24 \mathrm{~h}$. After incubation, the cells were harvested, washed thrice with PBS and lysed by incubating with $500 \mu \mathrm{l}$ of lysis buffer at $54{ }^{\circ} \mathrm{C}$ with gentle agitation for $2 \mathrm{~h}$ or until all solid material was digested. DNA was extracted with phenol: chloroform (24:1) (SD Fine Chem Limited, India) followed by ethanol (SD Fine Chem Limited, India) precipitation and the DNA pellet was air-dried. The DNA was resuspended in $20 \mu \mathrm{l}$ of TE buffer containing $50 \mu \mathrm{g} / \mathrm{ml}$ of RNase-A, incubated for $30 \mathrm{~min}$ at $37^{\circ} \mathrm{C}$, and analysed on a $1.5 \%$ agarose gel for DNA fragmentation. The gels were stained with $0.5 \mu \mathrm{g} / \mathrm{ml}$ of Ethidium Bromide and documented under UV transilluminator [23].

\section{RESULTS AND DISCUSSION}

\section{Synthesis of silver nanoparticles}

When the leaf extract of Withania somnifera, Aegle marmelos, Taraxacum officinale was mixed with AgNO3, the biosynthesis reaction started within few minutes. Clear AgNO3 solution changed into brown colour due to the excitation of surface plasmonic resonance (SPR) indicating the formation of AgNP (fig. 1).

The peak area at $430 \mathrm{~nm}$ increased with increase in reaction time at all concentrations revealing the maximum production of silver nanoparticles.
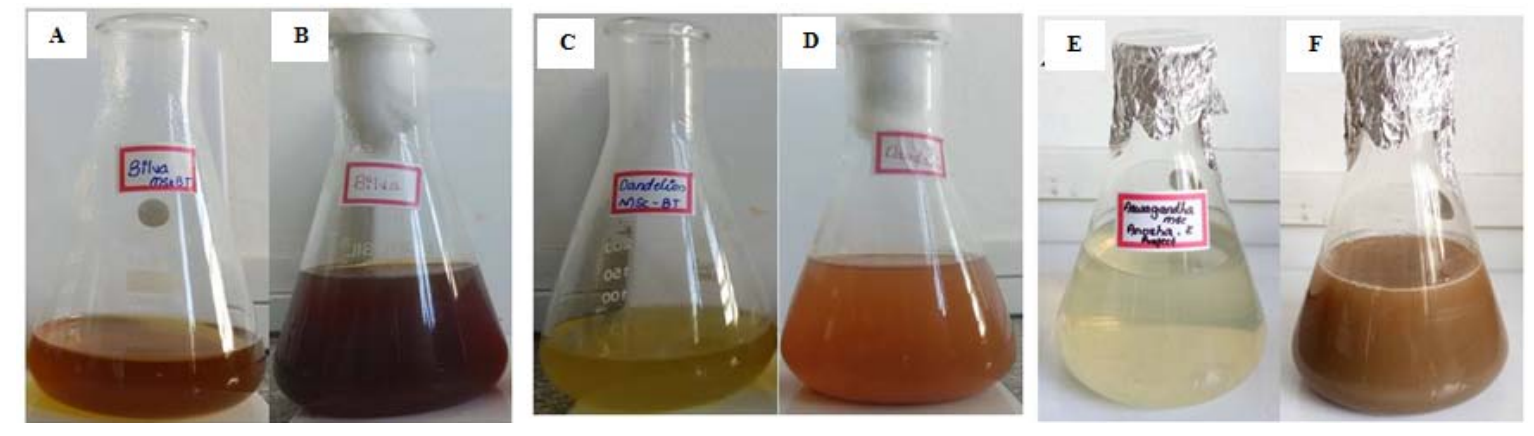

Fig. 1: Synthesis of silver nanoparticles using leaf extracts $(n=6)$. (A) Mixture of Aegle marmelos leaf extract and silver nitrate (1 mmol) before the synthesis of silver nano particles, (B) Brown solution after synthesis of silver nano particles (AgNP), (C) Mixture of Taraxacum officinale leaf extract and silver nitrate before synthesis, (D) Brown solution after synthesis of AgNP, (E) Mixture of Withania somnifera leaf extract and silver nitrate before synthesis, (F) Brown solution after synthesis of AgNP 


\section{Characterization of silver nano-particles}

\section{SEM analysis}

The bead for the SEM analysis was prepared by placing a drop of the silver nanoparticle suspension on the carbon tape attached to the head of cylindrical bead and it was dried inside a vacuum dryer for a couple of hours. The particles on the top of the bead were scanned by Scanning Electron Microscope and the images were obtained. Characterization of Aegle marmelos, Taraxacum officinale and Withania somnifera showed irregular shapes with a size of $26 \mathrm{~nm}, 18$ $\mathrm{nm}$ and $94 \mathrm{~nm}$ respectively (fig. 2).

\section{EDX spectroscopy}

In the present study, this technique was used to verify the presence of Ag and the curve showed a small peak of the element. EDX curve of Aegle marmelos (fig. 3) showed the presence of $\mathrm{Ag}$ and other elements like $\mathrm{K}, \mathrm{Na}, \mathrm{Mg}, \mathrm{C}$ and $\mathrm{O}$ (table 1), curve of Taraxacum officinale (fig. 4) sample showed the presence of $\mathrm{Ag}$ and other elements like $\mathrm{K}, \mathrm{Na}, \mathrm{Mg}, \mathrm{Cl}, \mathrm{C}$ and $\mathrm{O}$ (table 2) whereas curve of Withania somnifera (fig. 5) sample showed the presence of $\mathrm{Ag}$ and other elements like $\mathrm{P}, \mathrm{S}, \mathrm{K}, \mathrm{Na}, \mathrm{Mg}, \mathrm{Cl}, \mathrm{C}$ and $\mathrm{O}$ (table 3).

\section{FTIR analysis}

FTIR analysis of silver nanoparticle samples was carried out in order to obtain information about functional groups involved in reduction of silver nitrate. Compared to silver nitrate certain new prominent peaks of bands were observed in treated sample. These representative peaks contributed by the supernatant manifest the possible role of biomolecules mainly in reduction of silver nitrate to nano-particles. FTIR spectra of silver nano-particles synthesized by Aegle marmelos showed the absorbance peaks between 3431 to $3776 \mathrm{~cm}^{-1}$, indicating polyphenolic group along with $617 \mathrm{~cm}^{-1}$ aromatic $\mathrm{C} \mathrm{H}$ vibrations. Further, peaks at $1640 \mathrm{~cm}^{-1}$ represented the carbonyl groups (C 0) from polyphenols and alkanes (fig. 6a). FTIR spectra of silver nanoparticles synthesized by Taraxacum officinale showed the absorbance peaks at 3431 to $3776 \mathrm{~cm}^{-1}$, which indicated the presence of polyphenolic group along with $617 \mathrm{~cm}^{-1}$ aromatic $\mathrm{C} \mathrm{H}$ vibrations. Further, peaks at $1640 \mathrm{~cm}^{-1}$ represented carbonyl groups (C O) from polyphenols and alkanes (fig. 6b). FTIR spectra of silver nano-particles synthesized by Withania somnifera showed the absorbance peaks at 3431 to $3776 \mathrm{~cm}^{-1}$, indicated polyphenolic group along with $617 \mathrm{~cm}^{-1}$ aromatic $\mathrm{C} \mathrm{H}$ vibrations. Further, peaks at $1640 \mathrm{~cm}^{-1}$ represented carbonyl groups (C O) from polyphenols and alkanes (fig. 6c).
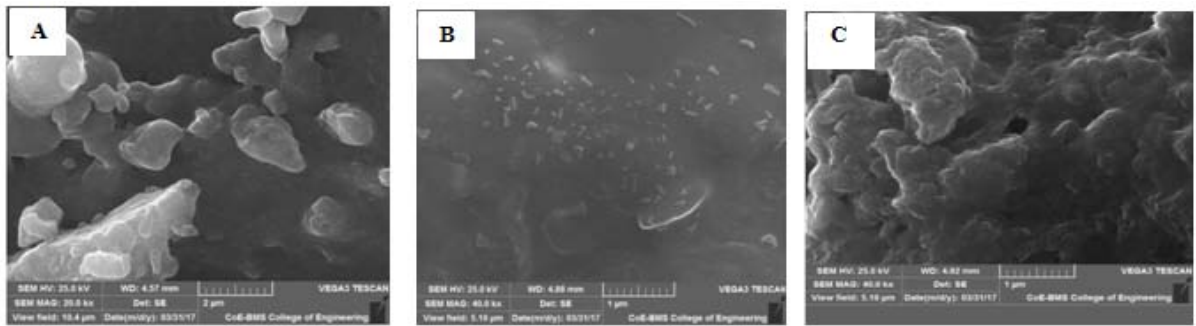

Fig. 2: SEM images of AgNPs synthesized by (A) Aegle marmelos (B) Taraxacum officinale (C) Withania somnifera

Table 1: Elemental composition of the nano particles synthesised by Aegle marmelos

\begin{tabular}{|c|c|c|c|c|c|}
\hline Element & Weight \% & Atomic \% & Net Int. & Error \% & K ratio \\
\hline $\mathrm{C} \mathrm{K}$ & 25.63 & 42.24 & 34.08 & 12.39 & 0.0697 \\
\hline $\mathrm{O} \mathrm{K}$ & 34.15 & 42.26 & 56.26 & 12.46 & 0.0418 \\
\hline $\mathrm{MgK}$ & 1.02 & 0.83 & 10.93 & 25.24 & 0.0037 \\
\hline $\mathrm{ClK}$ & 10.66 & 5.95 & 230.02 & 3.95 & 0.0934 \\
\hline $\mathrm{AgL}$ & 17.77 & 3.26 & 172.52 & 5.56 & 0.1501 \\
\hline $\mathrm{K} \mathrm{K}$ & 10.77 & 5.45 & 188.09 & 4.39 & 0.0895 \\
\hline
\end{tabular}

Elemental composition of Aegle marmelos showing the presence of Ag and other elements like $\mathrm{K}, \mathrm{Na}, \mathrm{Mg}$, Cnanoparticlesand $\mathrm{O}$.

Table 2: Elemental composition of the nano particles synthesised by Taraxacum officinale

\begin{tabular}{|c|c|c|c|c|c|}
\hline Element & Weight \% & Atomic \% & Net Int. & Error \% & K ratio \\
\hline $\mathrm{C} \mathrm{K}$ & 25.19 & 38.06 & 48.47 & 9.58 & 0.1286 \\
\hline $\mathrm{OK}$ & 43.13 & 48.93 & 65.19 & 12.05 & 0.0628 \\
\hline $\mathrm{NaK}$ & 4.61 & 3.64 & 18.22 & 16.43 & 0.0104 \\
\hline $\mathrm{MgK}$ & 1.83 & 1.37 & 13.88 & 19.19 & 0.0061 \\
\hline AgL & 12.56 & 2.11 & 101.26 & 7.50 & 0.1136 \\
\hline $\mathrm{K} \mathrm{K}$ & 12.68 & 5.89 & 181.82 & 3.34 & 0.1114 \\
\hline
\end{tabular}

Elemental composition of Taraxacum officinale showing the presence of Ag and other elements like $\mathrm{K}, \mathrm{Na}, \mathrm{Mg}, \mathrm{C}, \mathrm{Cl}$ and $\mathrm{O}$.

Table 3: Elemental composition of the nano particles synthesised by Withania somnifera

\begin{tabular}{|c|c|c|c|c|c|}
\hline Element & Weight \% & Atomic \% & Net Int. & Error \% & K ratio \\
\hline $\mathrm{C} \mathrm{K}$ & 30.14 & 45.45 & 44.00 & 11.09 & 0.1053 \\
\hline $\mathrm{OK}$ & 36.47 & 41.30 & 55.66 & 12.40 & 0.0485 \\
\hline $\mathrm{NaK}$ & 2.97 & 2.34 & 13.52 & 19.16 & 0.0070 \\
\hline $\mathrm{MgK}$ & 1.48 & 1.11 & 13.22 & 20.92 & 0.0053 \\
\hline P K & 1.03 & 0.60 & 16.45 & 23.72 & 0.0074 \\
\hline S K & 1.54 & 0.87 & 28.18 & 12.37 & 0.0127 \\
\hline $\mathrm{ClK}$ & 3.30 & 1.69 & 58.24 & 10.12 & 0.0277 \\
\hline $\mathrm{AgL}$ & 13.67 & 2.29 & 116.45 & 7.76 & 0.1186 \\
\hline $\mathrm{K} \mathrm{K}$ & 9.39 & 4.35 & 143.37 & 4.23 & 0.0799 \\
\hline
\end{tabular}

Elemental composition of Withania somnifera showing the presence of Ag and other elements like S, P, K, Na, Mg, C, Cl and O. 

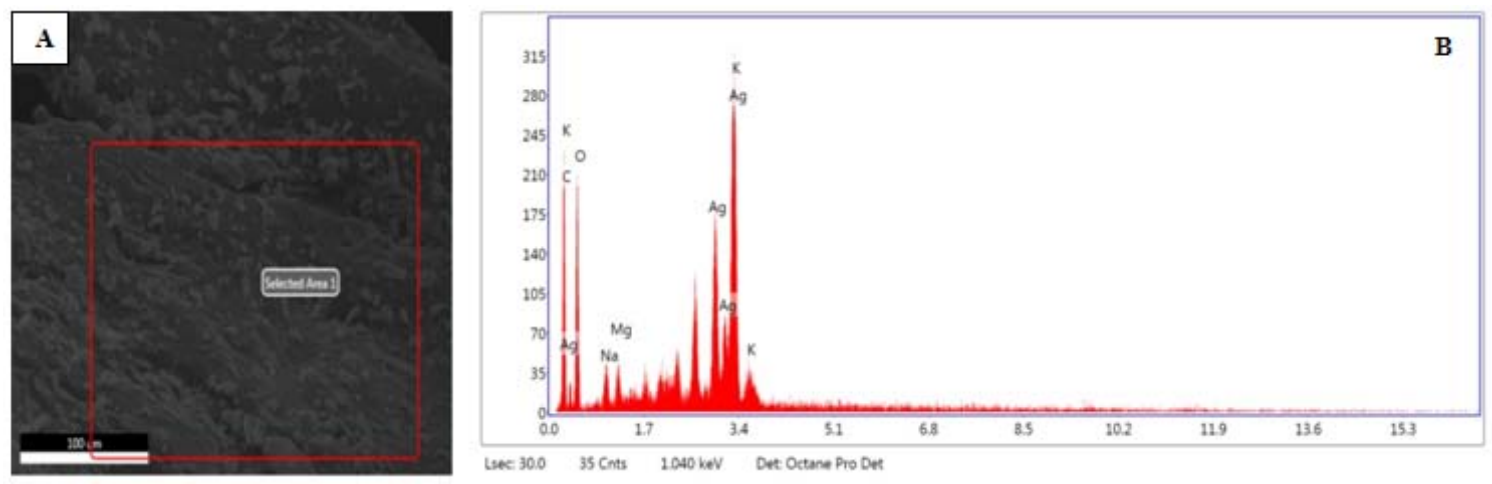

Fig. 3: EDX Characterization of nanoparticles synthesized by Aegle marmelos (A) Selected area from SEM image for characterization (B) EDX spectrum of Aegle marmelos showing the presence of $\mathrm{Ag}$ and other elements like $\mathrm{K}, \mathrm{Na}, \mathrm{Mg}$, $\mathrm{C}$ and $\mathrm{O}$
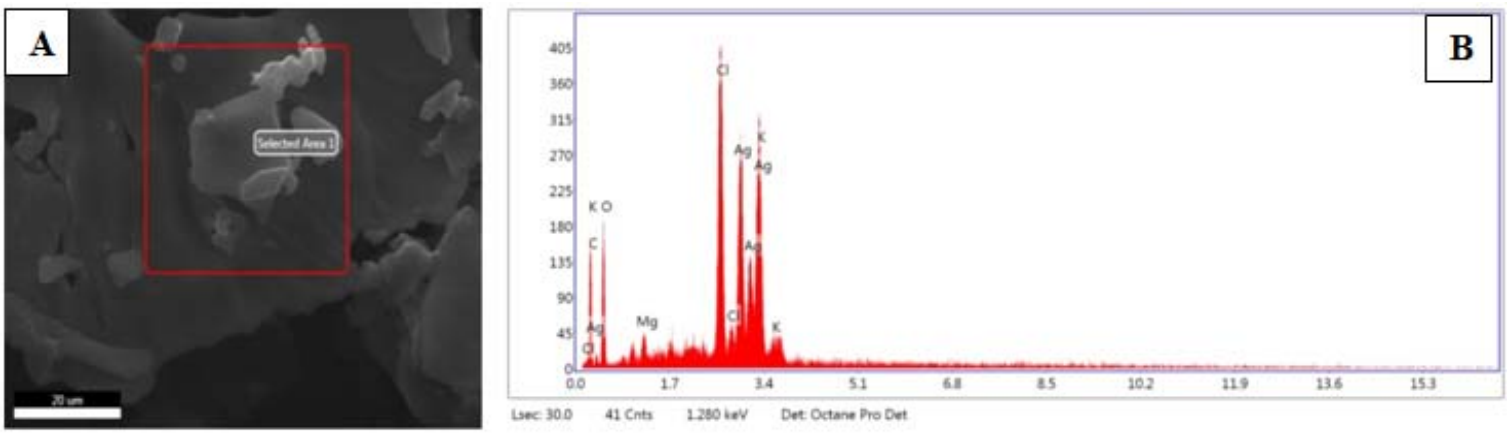

Fig. 4: EDX Characterization of nanoparticles synthesized by Taraxacum officinale (A) Selected area from SEM image for characterization (B) EDX spectrum of Taraxacum officinale showing the presence of $\mathrm{Ag}$ and other elements like $\mathrm{K}, \mathrm{Na}, \mathrm{Mg}, \mathrm{C}, \mathrm{Cl}$ and $\mathrm{O}$
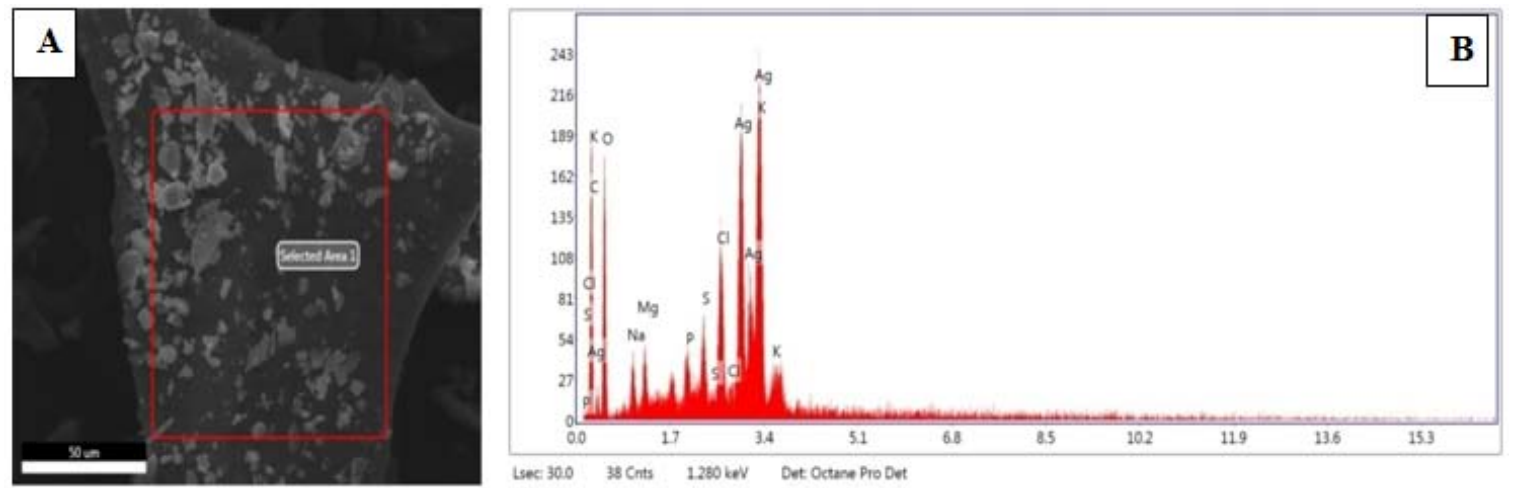

Fig. 5: EDX Characterization of nanoparticles synthesized by Withania somnifera (A) Selected area from SEM image for characterization (B) EDX spectrum of Withania somnifera showing the presence of $\mathrm{Ag}$ and other elements like $\mathrm{S}, \mathrm{P}, \mathrm{K}, \mathrm{Na}, \mathrm{Mg}, \mathrm{C}, \mathrm{Cl}$ and $\mathrm{O}$
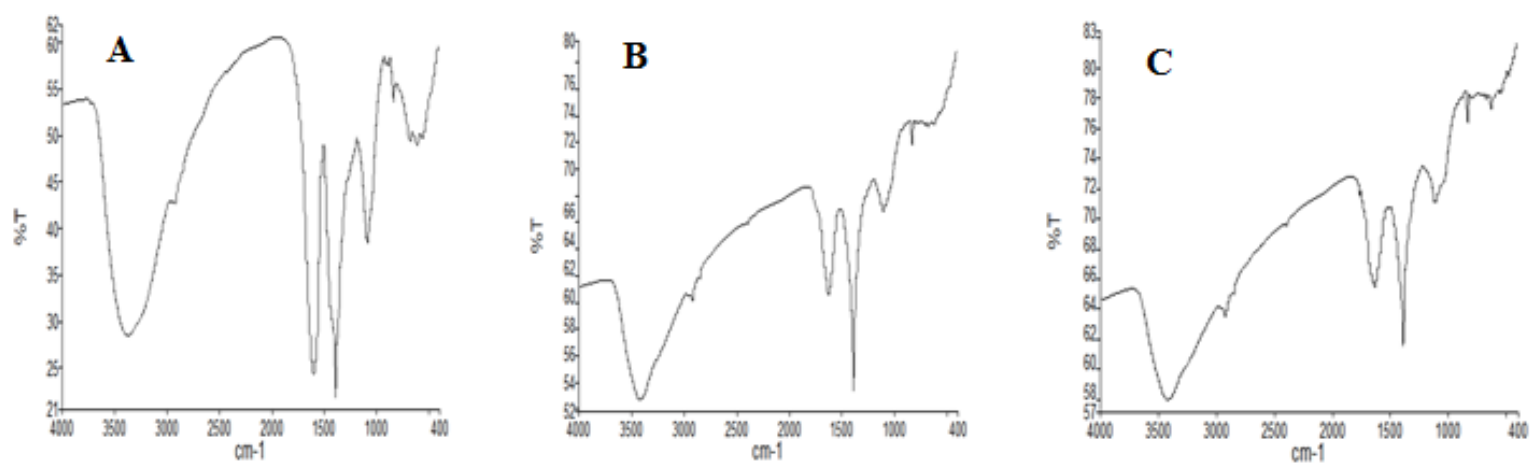

Fig. 6: FTIR Characterization of AgNPs in extracts containing (A) Aegle marmelos (B) Taraxacum officinale (C) Withania somnifera 


\section{In vitro cytotoxicity assay}

\section{MTT assay}

The anticancer activity of the synthesized silver nano-particles were evaluated in vitro against MCF-7 breast cancer cell lines after $24 \mathrm{~h}$ exposure and their IC50 values were determined from a graph of cell viability measured over a range of concentrations between 25 and $500 \mathrm{\mu g} / \mathrm{ml}$. The IC50 was determined at a broad range of concentrations specifically $25,50,100,250,500 \mu \mathrm{g} / \mathrm{ml}$ against the cell lines. With this data, a line graph was plotted between concentrations (X-axis) versus \% inhibition (Y-axis) and then an intersection drawn at $50 \%$ inhibition on Y-axis and then correlated to the concentration value on X-axis. From the data, it is revealed that silver nanoparticle exhibited different range of significant cytotoxic activities varying from $25 \mu \mathrm{g} / \mathrm{ml}$ to $500 \mu \mathrm{g} / \mathrm{ml}$ due to structural differences.

According to the results obtained, the IC50 value was $251.2563 \pm 0.59 \mu \mathrm{g} / \mathrm{ml}$ (fig. 7), $215.5172 \pm 0.41 \mu \mathrm{g} / \mathrm{ml}$ (fig. 8) and $205.7613 \pm 0.37 \mu \mathrm{g} / \mathrm{ml}$ (fig. 9) for Aegle marmelos, Taraxacum officinale and Withania somnifera respectively against MCF-7Cells. Based on IC50 values, Withania somnifera got the better values hence its further studies for apoptosis and DNA fragmentation were carried out.
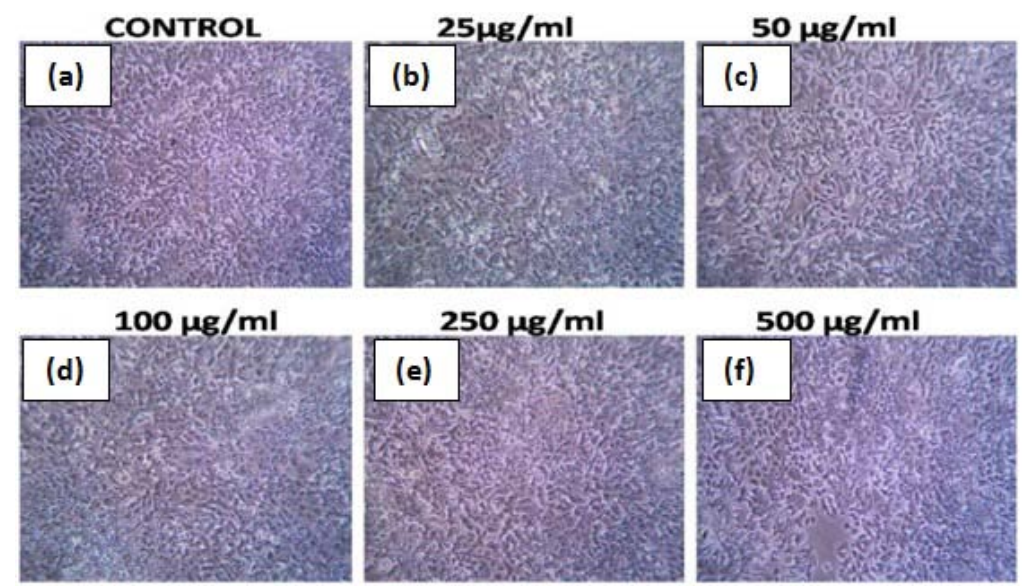

(A)

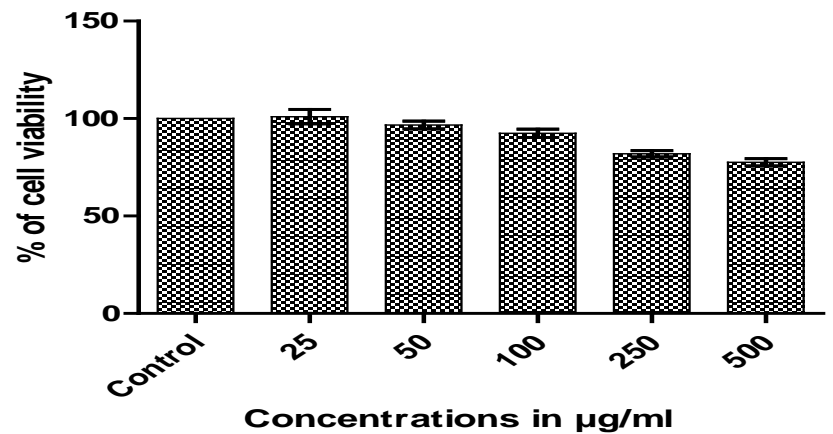

(B)

Fig. 7: (A) Cytotoxic effect of Aegle marmelos synthesized AgNP on MCF-7 cell line (n=6). (a) Control, (b) 25, (c) 50, (d) 100, (e) 250 and (f) $500 \mu \mathrm{g} / \mathrm{ml}$. (B) Cytotoxic effect of Aegle marmelos synthesized AgNP on MCF-7 cell line (n=6)

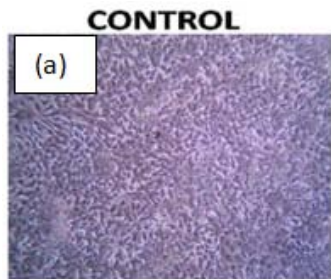

$100 \mu \mathrm{g} / \mathrm{ml}$

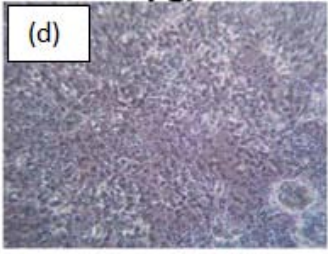

$25 \mu \mathrm{g} / \mathrm{ml}$

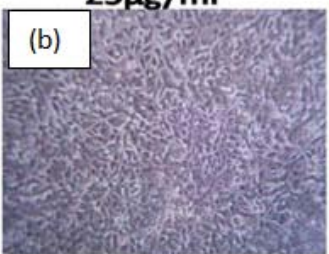

$250 \mathrm{\mu g} / \mathrm{ml}$

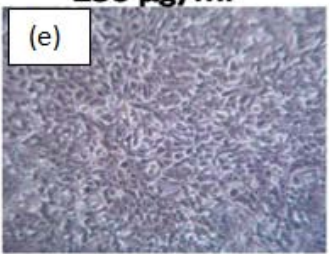

$50 \mathrm{\mu g} / \mathrm{ml}$

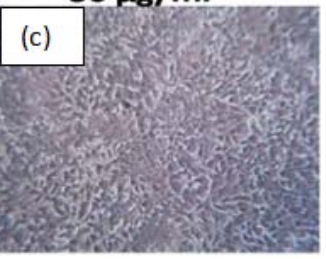

$500 \mu \mathrm{g} / \mathrm{ml}$

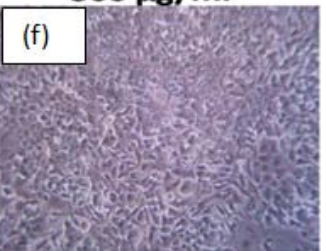

(A) 


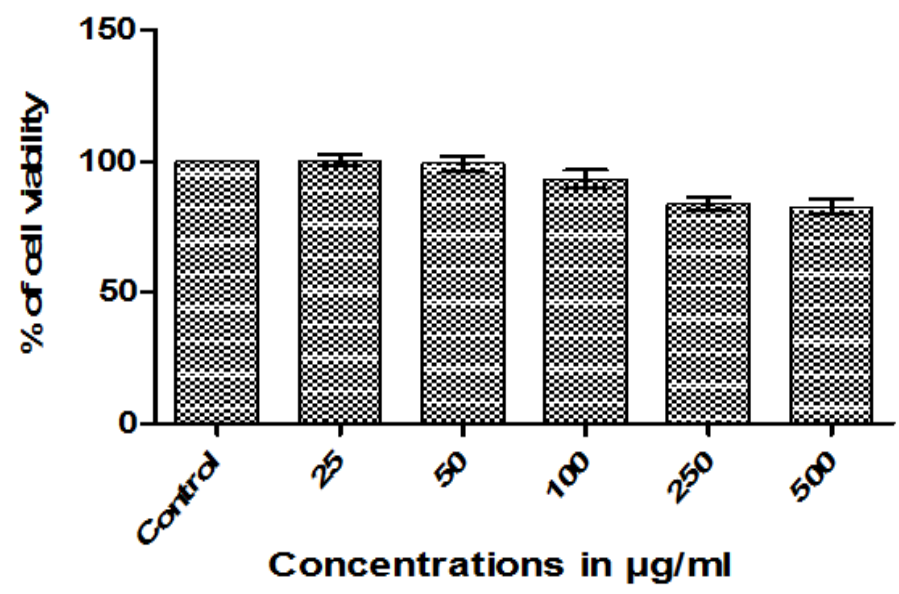

(B)

Fig. 8: (A) Cytotoxic effect of Taraxacum officinale synthesized AgNP on MCF-7 cell line (n=6). (a) Control, (b) 25, (c) 50, (d) 100, (e) 250 and (f) $500 \mu \mathrm{g} / \mathrm{ml}$. (B) Cytotoxic effect of Taraxacum officinale synthesized AgNP on MCF-7 cell line (n=6)

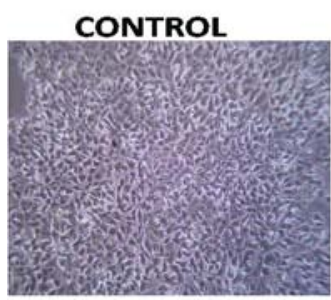

$100 \mu \mathrm{g} / \mathrm{ml}$

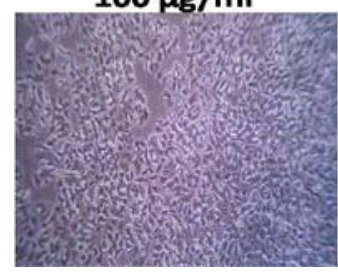

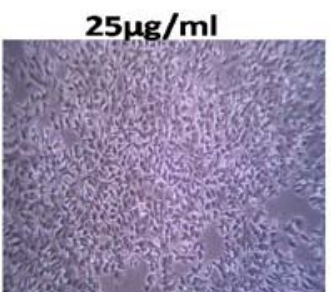

$250 \mu \mathrm{g} / \mathrm{ml}$

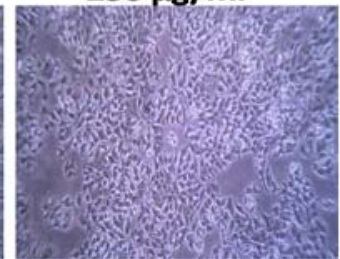

(A)

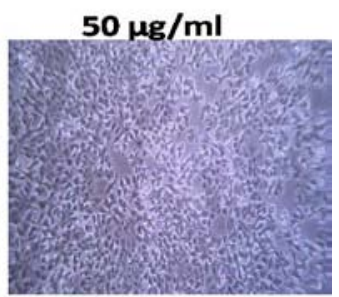

$500 \mu \mathrm{g} / \mathrm{ml}$

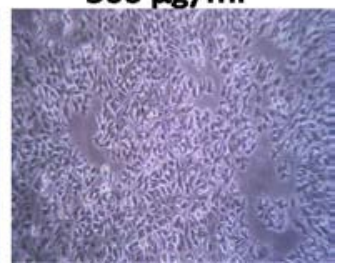

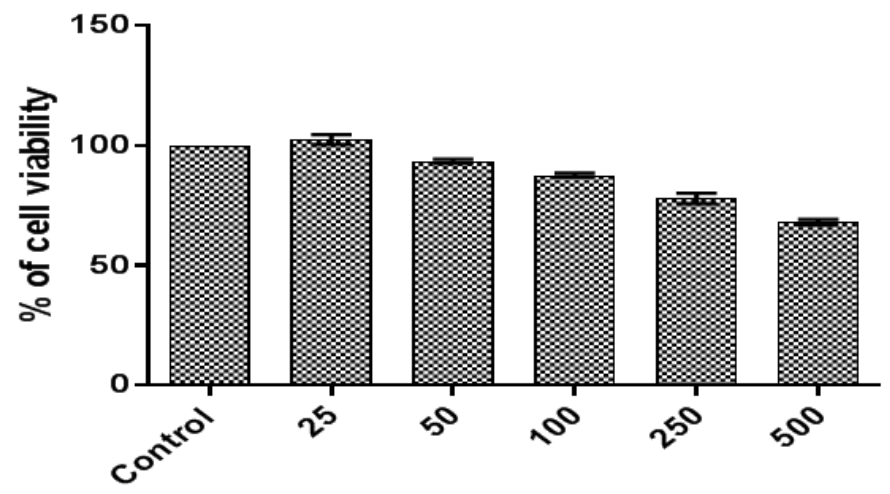

Concentrations in $\mu \mathrm{g} / \mathrm{ml}$

(B)

Fig. 9: (A) Cytotoxic effect of Withania somnifera synthesized AgNP on MCF-7 cell line (n=6). (a) Control, (b) 25, (c) 50, (d) 100, (e) 250 and (f) $500 \mu \mathrm{g} / \mathrm{ml}$. (B) Cytotoxic effect of Withania somnifera synthesized AgNP on MCF-7 cell line ( $\mathrm{n}=6$ )

\section{Apoptosis-necrosis assay}

Morphological evidence of apoptosis by dual staining: Apoptotic morphological changes caused by silver nano-particles were studied using acridine orange/ethidium bromide differential staining method. The stained cells were characterized to viable (light green), early apoptotic (bright green fluorescence and condensed chromatin), late apoptotic (orange fluorescence) and nonviable cells (red coloured fluorescence). Silver nano-particles treated cells showed condensed nuclei, membrane blebbing and apoptotic bodies (fig. 10). In contrast, the control cells showed intact nuclear architecture. 


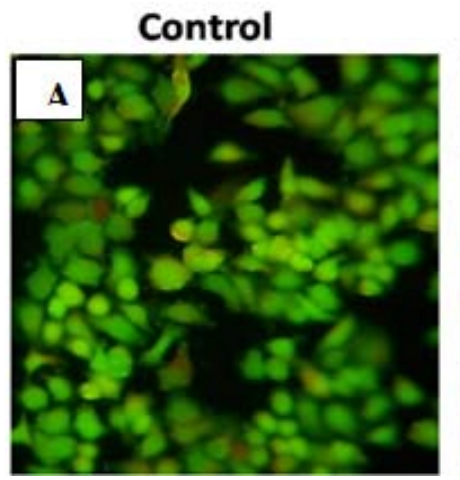

\section{Treated $500 \mu \mathrm{g} / \mathrm{ml}$}

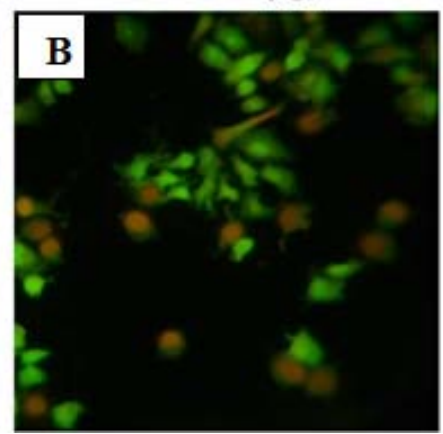

Fig. 10: Detection of apoposis by AO/EB dual staining (A) Control MCF-7 cells (B) MCF-7 cells treated with $500 \mu \mathrm{g} / \mathrm{ml}$ of Withania somnifera synthesized AgNP

\section{DNA fragmentation assay}

The evaluation of apoptosis was further carried out by determining the DNA fragmentation patterns, MCF-7 cells were treated with the extracts, failed to show characteristics of DNA laddering when treated at low concentration $(500 \mu \mathrm{g} / \mathrm{ml})$. The difference in effect towards cancer cells could be targeting a particular molecular event exclusively in tumor cells and showed that the silver nano-particles treated did not exhibit extensive double strand breaks, thereby not yielding a ladder appearance, while the DNA of control cells supplemented with $10 \%$ serum exhibited minimum breakage (fig. 11).

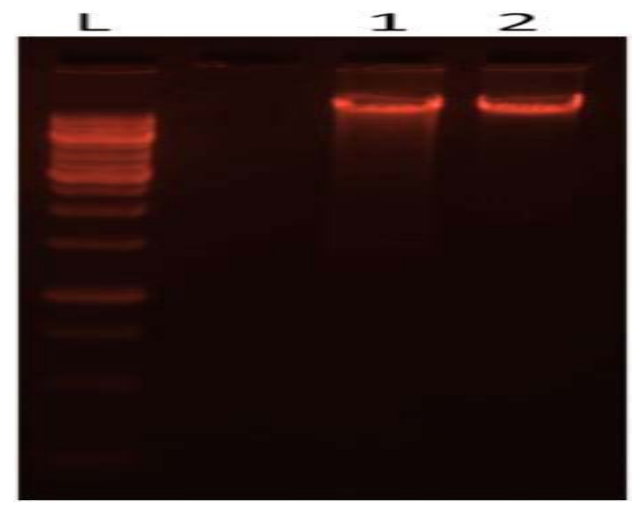

Fig. 11: DNA Fragmentation assay. MCF7 cell lines treated with Withania somnifera synthesized AgNP (L-DNA ladder, Lane 1Untreated MCF-7 cell line and Lane 2-MCF-7 cells treated with $500 \mu \mathrm{g} / \mathrm{ml}$ of extract)

Several approaches have been made to study the anti-cancer efficacy of silver nano-particles synthesized from three different plant extracts namely: Withania somnifera, Aegle marmelos, Taraxacum officinale leaves. These nano-particles were used against MCF-7 cell line. The synthesized nano-particles where characterized to study their size and chemical composition using SEM, EDX and FTIR analysis. Further, their in vitro cytotoxicity on MCF-7 cells was studied through MTT, Apoptosis and DNA Fragmentation Assay.

Synthesis of nano-particles from the leaves of Withania somnifera, Aegle marmelos, Taraxacum officinale yielded a brown color solution which gradually increased with increase in reaction time. This is comparable to the work performed by Arokiyaraja et al., 2015 [24] where aqueous extracts of Taraxacum officinale was used to synthesize silver nano-particles.

Characterisation of Aegle marmelos yielded nano-particles of the size $26 \mathrm{~nm}$, with the presence of $\mathrm{Ag}$ and other elements like $\mathrm{K}, \mathrm{Na}, \mathrm{Mg}, \mathrm{C}$ and 0 . Further the FTIR characterization indicated the presence of polyphenolic groups and carbonyl groups. Similar studies were performed by Patil et al., 2015 [20] and Prasannaraj and Venkatachalam., 2017 [25]. The MTT assay of these nano-particles showed an IC50 value of $251.2563 \mu \mathrm{g} / \mathrm{ml}$ against MCF-7 cells. Comparable study was performed by Prasannaraj and Venkatachalam. 2017 [25] which indicated the anti-cancer efficacy of nanoparticles synthesized by Aegle marmelos on HepG2 and PC3 cell lines.

SEM analysis of Taraxacum officinale yielded results that showed the particle size as $18 \mathrm{~nm}$. Further the EDX characterization showed the presence of $\mathrm{Ag}$ and other elements like $\mathrm{K}, \mathrm{Na}, \mathrm{Mg}, \mathrm{Cl}, \mathrm{C}$ and $\mathrm{O}$. This is in agreement with studies performed by Arokiyaraja et al.,2015 [24]. MTT assay demonstrated an IC50 value of $215.51 \mu \mathrm{g} / \mathrm{ml}$ against MCF-7 Breast Cancer cells lines.

Characterization of Withania somnifera yielded silver nano-particles of size $94 \mathrm{~nm}$ with presence of $\mathrm{Ag}$ and other elements like $\mathrm{P}, \mathrm{S}, \mathrm{K}, \mathrm{Na}$, $\mathrm{Mg}, \mathrm{Cl}, \mathrm{C}$ and $\mathrm{O}$. Similar studies on nano-particles synthesized from Aegle marmelos was performed by Prasannaraj and Venkatachalam.,2017 [25]. MTT assay exhibited an IC50 value of $205.7613 \mu \mathrm{g} / \mathrm{ml}$ against MCF-7 Breast Cancer cell lines. Apoptotic analysis further showed that they induced apoptosis in the cancer cells, unlike DNA fragmentation which did not show fragmentation.

\section{CONCLUSION}

The present study concludes bio synthesis of silver nano particles synthesized by plant extracts especially of Withania somnifera, Aegle marmelos, Taraxacum officinale which show promising results for biomedical applications. Green synthesis of nanoparticles is a simple, cost effective and eco-friendly way compared to other chemical procedures. The findings of this study indicate that the plant extracts especially of Withania somnifera could provide an alternative to the currently available chemotherapy, in order to improve the quality of life of breast cancer patients and possibly provide a more efficient mode of treatment while doing so.

\section{AUTHORS CONTRIBUTIONS}

All the authors have contributed equally

\section{CONFLICT OF INTERESTS}

\section{Declared none}

\section{REFERENCES}

1. Huy Tran Q, Nguyen VQ, Anh Tuan Le. Silver nano-particles: synthesis, properties, toxicology, applications and perspectives. Adv Nat Sci: Nanosci Nanotechnol 2011;4:120.

2. Ju-Nam Y, Lead JR. Manufactured nanoparticles: an overview of their chemistry, interactions and potential environmental implications. Sci Total Environ 2008;400:396-414.

3. Sharma VK, Yngard RA, Yekaterina Lin. Silver nano-particles: green synthesis and their antimicrobial activities. Adv Colloid Interface Sci 2009;145:83-96.

4. Siavash Iravani. Green synthesis of metal nano-particles using plants. Green Chem 2011;13:2638-50. 
5. Mahendra Rai, Alka Yadav, Aniket Gade. Silver nano-particles as a new generation of antimicrobials. Biotechnol Adv 2009;27:76-83.

6. Kim JS, Kuk E, Yu KN, Kim JH, Park SJ, Lee HJ, et al. Antimicrobial effects of silver nano-particles. Nanomedicine 2007;3:95-101.

7. Morones JR, Elechiguerra JL, Camacho A, Holt K, Kouri JB, Ramirez JT, et al. The bactericidal effect of silver nano-particles. Nanotechnology 2005;16:2346-53.

8. Retchkiman Schabes PS, Canizal G, Becerra Herrera R, Zorrilla C, Liu HB, Ascencio JA. Biosynthesis and characterization of Ti/Ni bimetallic nano-particles. Opt Mater 2006;29:95-9.

9. Gu H, Ho PL, Tong E, Wang L, Xu B. Presenting vancomycin on nano-particles to enhance antimicrobial activities. Nano Lett 2003;3:1261-3.

10. Gong P, Li H, He X, Wang K, Hu J, Tan W, et al. Preparation and antibacterial activity of Fe304@Ag nano-particles. Nanotechnology 2007;18:604-11.

11. Rob Sanson Fisher, Afaf Girgis, Allison Boyes, Billie Bonevski, Louise Burton, Peter Cook. The Unmet supportive care needs of patients with cancer. ACS Cancer News 2000;88:226-37.

12. Katrien Vermeulen, Dirk R Van Bockstaele, Zwi N Berneman. The cell cycle: a review of regulation, deregulation and therapeutic targets in cancer. Cell Prol 2003;36:131-49.

13. Mousavi SM, Ali Montazeri, Mohagheghi MA, Jarrahi AM, Iraj Harirchi, Masomeh Najafi, et al. Breast cancer in Iran: an epidemiological review. Breast J 2007;13:383-91.

14. Carey LA, Perou CM, Livasy CA, Dressler LG, David Cowan, Kathleen Conway, et al. Race, breast cancer subtypes, and survival in the carolina breast cancer study. JAMA 2006;295:2492-502.

15. Paul DP Pharoah, Nicholas E Day, Stephen Duffy, Duglas F Easton, Bruce AJ Ponder. Family history and the risk of breast cancer: a systematic review and meta-analysis. Int J Cancer 1997;71:800-9.

16. Rajarajan P, Senthil kumar R. Assessment of antineoplastic potential of annona reticulata linn. on human cancer cell lines. Asian J Pharm Clin Res 2016;9:408-11.
17. Patcharaporn Tippayawat, Nutthakritta Phromviyo, Parichart Boueroy, Apiwat Chompoosor. Green synthesis of silver nanoparticles in Aloe vera plant extract prepared by a hydrothermal method and their synergistic antibacterial activity. Peer J 2016;4:e2589.

18. Elizabath Antony, Mythili Sathiavelu, Sathiavelu Arunachalam. Synthesis of silver nanoparticles from the medicinal plant bauhinia acuminata and biophytum sensitivum-a comparative study of its biological activities with plant extract. Int J Appl Pharm 2017;9:22-9.

19. Madhumithra SK, Balashanmugam P, Mosachristas K, Tamil selvi A, Subashini R. In vitro cytotoxicity of biosynthesized gold nanoparticles from shells of Pistacia vera L. Int J Appl Pharm 2018;10:162-7.

20. Sunita Patil, Rajeshwari Sivaraj, Rajiv P, Rajendran Venckatesh, Seenivasan R. Green synthesis of silver nanoparticle from leaf extract of Aegle marmelos and evaluation of its antibacterial activity. Int J Pharm Pharm Sci 2015;7:169-73.

21. Anupama Thapliyal, Amrish Chandra. Antibacterial and anticancer potential of silver nanoparticles synthesized using gallic acid in bentonite/starch bio-nanocomposites. Int J Appl Pharm 2018;5:178-89.

22. Kuan Liu, Peng-cheng Liu, Run Liu, Xing Wu. Dual AO/EB staining to detect apoptosis in osteosarcoma cells compared with flow cytometry. Med Sci Monit Basic Res 2015;21:1525.

23. Gavrieli Y, Sherman Y, Ben Sason SA. Identification of programmed cell death in situ via specific labeling of nuclear DNA fragmentation. J Cell Biol 1992;119:493-501.

24. Arokiyaraja S, Saravanan M, Vijayakumar B. Green synthesis of Silver nano-particles using aqueous extract of Taraxacum officinale and its antimicrobial activity. South Ind J Biol Sci 2015;1:115-8.

25. Prasannaraj G, Venkatachalam P. Green engineering of biomolecule-coated metallic silver nanoparticles and their potential cytotoxic activity against cancer cell lines. Adv Nat Sci: Nanosci Nanotechnol 2017;8:025001. 